Прегледни чланак

Stefan V. Stojanović, Research Assistant, Ph.D. Student

University of Niš

Innovation Center

stojanovicst91@gmail.com

\title{
ROMAN PROPERTY LAW IN COMPARATIVE ANALYSIS OF THE INSTITUTES OF GAIUS AND THE INSTITUTES OF JUSTINIAN*
}

\begin{abstract}
In this paper comparison of the provisions of Roman property law in the Institutes of Gaius and the Institutes of Justinian has been made. The aim of this paper is to find out which provisions of the Institutes of Gaius were reciprocated in the Institutes of Justinian, and which were not, and whether certain provisions were taken with modification and what the modification consists of. In this way, it will be determined which institutes of Roman property law remained unchanged until Justinian's time, which underwent changes, and which, due to changes in social relations, don't exist anymore. The comparative method will analyze the most important legal concepts and institutes of Roman property law from the Institutes.
\end{abstract}

Keywords: Roman law, property law, Institutes of Gaius, Institutes of Justinian.

\section{INTRODUCTION}

In this paper, a comparative analysis of the provisions which governs the institutes of Roman property law of the Institutes of Gaius and the Institutes of Justinian, has been made. Institutes of Justinian have Gaius as their basis. The editors of the Institutes of Justinian (Tribonian, Theophilus, and Dorotheus) also pointed out this: "These Institutes, extracted from all the old Institutes, from many Commentaries, but mostly from the Commentary of our Gaius ..."1 This is evident

\footnotetext{
${ }^{*}$ The paper is the result of research based on the obligations of the Agreement on the realization and financing of scientific research work of the Innovation Center University of Niš in 2020. (ev. br. 451-03-68/2020-14/200371)

${ }^{1}$ The paper uses a translation of Institutes of Justinian by Lujo Bakotić: Caesar Flavius Justinianus: Institutiones, Београд 1912.
} 
from the structure of Institutes of Justinian, since it fits the structure of Institutes of Gaius. The whole theme in both, is divided into four books, that is, commentaries. ${ }^{2}$ Institutes of Justinian accept Gaius division of rights, so here matter is exposed according to the system of tripartition: personae (personal rights), res (property rights) and actiones (court proceedings).

The provisions of property law are in the first half of the second commentary (book). The aim of the paper is to determine which provisions of the Institutes of Gaius are reciprocated in the Justinian's, which are reciprocated with the modification (and what the modification consists of), and which don't have their own model in the Gaius. It will also point to the provisions of the Gaius which have not been taken over by the Institutes of Justinian. In this way, it will be determined which institutes of Roman property law remained unchanged until Justinian's time, which underwent certain changes, and which, due to changes in social relations, don't exist. The comparative method will analyze the most important legal concepts and institutes of Roman property law from the Institutes: things and their division, property and ways of acquiring property, usucapion and servitude.

\section{THINGS}

Neither Gaius nor the Justinian's Institutes define the concept of things (res). Both Institutes start with division of things (de rerum divisione).

There are different criteria for dividing things. The basic division is into things in legal circulation (res in commercio) and things outside legal circulation (res extra commercium). Things are out of legal circulation either "by human law" (res extra commercium humani iuris) or "by divine law" (res extra commercium divini iuris). ${ }^{3}$

Institutes of Justinian are paying more attention to matters that are outside the legal circulation "by human law" (res extra commercium humani iuris) than Gaius. They contain many articles that list these things, and that do not have their pendant in Gaius. These things are: air, running water, sea and seashores (Just. Inst. 2. I. 1. aer et aqua profluens et mare et per hoc liters maris), ports and rivers (Just. Inst. 2. I. flumina autem omnia et portus publica), river banks (Just. Inst. 2. I. 4. riparum), use of shores and seas (Just. Inst. 2. I. 5. litorum quoque usus publicus iuris gentium est, sicut ipsius maris) as well as res universitatis belonging to associations (municipalities), such as theaters and racetracks in cities (Just. Inst. 2. I. 6. theatra et stadia). On these matters, Gaius merely states that public goods

${ }^{2}$ Institutes of Gaius" use the term „,commentary“ (commentarius), and Justinian's „,book“ (liber).

${ }^{3}$ Gaius, Inst. 2. 2. Summa itaque rerum divisio in duos articulos diducitur: nam aliae sunt divini iuris, aliae humani (The basic, then, division of things comes down to two types: some are out of legal circulation by divine law, the other out of human law). The paper uses a translation of Instites of Justinian by professor Obrad Stanojević: Гај, Инсӣийуције, Београд 2009. 
are considered not to belong to anyone's property but to the community itself. ${ }^{4}$ This provision was not reciprocated in Institutes of Justinian, but its essence was expressed by a different nomotechnic. Instead of a general provision, editors have chosen to determine, through examples in several articles, what is in the public domain. Since the Institutes of Justinian were a legal textbook at state colleges (with legal force), it is likely that this enumeration was intended to bring law students closer to understanding all things that constitute public goods.

When we talk about things that are outside the legal circulation "by divine law" (res extra commercium divini iuris), both Institutes contain provisions governing the legal regime of these goods. Gaius says that what belongs to divine right cannot be in anyone's property. ${ }^{5}$ In Institutes of Justinian, this provision is modified by determining what categories of things are by divine law. ${ }^{6}$ These things are res sacrae (those that belong to temples and serve religious ceremonies), res religiosae (things dedicated to the cult of the dead), and res sanctae (things that are declared holy). Res sacrae (sacral things) are those which are consecrated to the celestial deities, ${ }^{7}$ and the sacred place is one which has been proclaimed as such by the decision of the Roman people - by law or by Senate decision. ${ }^{8}$ The Institutes of Justinian modify these provisions in such a way that they determine that sacred (religious) things are those intended for God by priests, such as religious buildings (churches) and things intended for the service of God. ${ }^{9}$ Modification of the relevant provisions of the Institutes of Gaius was influenced by Christianity. The provision stipulating that the one who buries the deceased on his land consecrates the land, and it becomes res religiosae ${ }^{10}$ is taken from the Gaius (Gaius, Inst. 2. 6). The mentioned provision of the Institutes of Justinian also contains an annex which provides for an obligation for the one who wishes to bury the deceased on someone else's land to seek the permission of the landowner, but if he buries the deceased even before obtaining this permission, the land still becomes res religiosae. ${ }^{11}$ The provision of the Institutes of Gaius according to which sacred things (res sanctae),

${ }^{4}$ Gaius, Inst. 2. 11. Quae publicae sunt, nullius videntur in bonis esse; ipsius enim universitatis esse credentur.

${ }^{5}$ Gaius, Inst. 2. 9. Quod autem divini iuris est, id nullius in bonis est.

${ }^{6}$ Just. Inst. 2. I. 7. Nullius autem sunt res sacrae et religiosea et sanctae: quod enim divini iuris est, id nullius in bonis est. Also, this division is cited by Institutes of Gaius (Gaius, Inst. II. 3. Divini iuris sunt veluti res sacrae et religiosae). Here Gaius dropped the third category - res sanctae. They are discussed in Article 9 (Gaius, Inst. II. 9).

${ }^{7}$ Gaius, Inst. 2. 4. Sacrae sunt quae diis superis consecrate sunt...

${ }^{8}$ Gaius, Inst. 2. 5. Sed sacrum quidem hoc solum existimatur quod ex auctoritate populi Romani consecratum est, veluti lege de ea re lata aut senatusconsulto facto.

${ }^{9}$ Just. Inst. 2. I. 8. Sacra sunt, quae rite et per pontifices deo consecrata sunt...

${ }^{10}$ Just. Inst. 2. I. 9. Religiosum locum unusquisque sua voluntate facit, dum mortuum infert in locum suum.

${ }^{11}$ Just. Inst. 2. I. 9. ...in alienum locum conceddeate domino licet inferre: et liceta postea ratum habuerit, quam illatus est mortuus, tamen religiosus locus fit. 
such as city walls and gates, belong to divine law, ${ }^{12}$ was taken up in the Justinian's with the prescription of a criminal sentence, the death penalty for those who would in any criminal way damage the walls. ${ }^{13}$ Therefore, these things also have criminal protection, since this is a particularly serious crime (sacrilegium) for which the death penalty is provided. This punishment for criminal act also existed in Gaius time, and as it was well known Gaius had no need to mention it.

The following division of things, contained in both Institutes, is into corporeal (res corporales) and not-corporeal (res incorporales) things. Some things are corporeal and some are not-corporeal. ${ }^{14}$ Corporeal things are those that can be touched, such as land, slave, clothing, gold, silver and many other things. ${ }^{15}$ Notcorporeal things are those that cannot be touched, such as those which consist in a right, such as legacy, ususfruct, obligations in any way..$^{16}$ Institutes of Justinian have fully taken up all these provisions (Just. Inst. 2. II. 1, 2, 3), but they had only theoretical value. Not-corporeal things could only be transmitted through ,court cession" (in iure cessio) because there could be no possession on them. When Justinian introduced the possession of not-corporeal things (quasi possessio), this distinction lost its practical significance.

The division of things into res mancipi and res nec mancipi is contained in the Institutes of Gaius (Gaius. Inst. 2. 14a, 15, 16, 17, 18), but it is overcome in Justinian's law, because the tradition (traditio) is sufficient mode of acquiring property rights, so his Institutes don't say anything about it. Why this division has lost its former significance, will be discussed in the section on modes to acquire property.

\section{PROPERTY AND THE MODES OF ACQUIRING IT}

Property is the most significant right to things. The Roman jurists didn't define in a direct way the term of property. The Institutes of Gaius don't define this institute. Institutes of Justinian indirectly regulate the term of property. Namely, when the usufruct stops (ususfructus), it was said that the owner, who until then had only "bare property" (nuda proprietas), from that moment he regains "complete authority on things" (plena in re potestas) ${ }^{17}$.

${ }^{12}$ Gaius, Inst. 2. 8. Sanctae quoque res, velut muri et portae, quodammodo divini iuris sunt.

${ }^{13}$ Just. Inst. 2. I. 10. ...ideo autem muros sanctos dicimus, quia poena capitis constituta sit in eos, qui aliquid in muros deliquerint.

${ }^{14}$ Gaius, Inst. 2. 12. Quaedam praeterea res corporales sunt, quaedam incorporales.

${ }^{15}$ Gaius, Inst. 2. 13. Corporales hae sunt quae tangi possunt, velut fundus homo vestis aurum argentum et denique aliae res innumerabiles.

${ }^{16}$ Gaius, Inst. 2. 14. Incorproales sunt quae tangi non possunt, qualia sunt ea quae iure consistunt, sicut hereditas, ususufructus, obligationes quoquo modo contractae.

${ }^{17}$ Just. Inst. 2. II. 4. Cum autem finitus fuerit usus fructus, revertitur scilicet propiretatem et ex eo tempore nudae proprietatis dominus incipit plenam habere in re potestatem. 
In this way, at least indirectly, Roman law introduced the concept of property. If we have in mind that property consists of three rights (usus - right to use things, fructus - right to acquire natural and civil fruits and abusus - right to factual and legal disposal), then this definition of property fully expresses the essence of this legal institute in Roman law.

Modes to acquire property (modus acquirendi) can be divided into derivative and original. Derivative modes of acquiring property are those in which the acquirer derives this right from his predecessor's rights, while the original acquirer bases this right on things that don't have the owner, that is, regardless of the will of the previous owner.

Derivative modes include mancipatio, in iure cessio and traditio. In iure cessio (fictitious litigation), in addition to the transfer of property rights, was also used for the circulation of other rights (for not-corporeal things it was the only mode of trade). Gaius states that it was also used for the transfer of city land servitude ${ }^{18}$, usufruct $^{19}$, inheritance ${ }^{20}$. In iure cessio has been out of use over time. The Romans, however, most often and almost always used mancipation. ${ }^{21}$ It took the form of per aes et libram, with the presence of a mancipant, a mancipator, five witnesses and an official surveyor (libripens). It was used to transfer property on res mancipi (land in Italy, slaves and livestock). Although from the beginning it had its justification to provide legal certainty through it, since in this way publicity was gained in the transfer of ownership of things important for human economy and even for its survival, over time it gained a legal political connotation. This happens when Rome becomes a state with a large territory inhabited by various nations, Roman citizensand also foreigners (peregrines). As a form for transferring property rights to ius civile, it was only available to Roman citizens (cives Romani). In this way, foreigners were prevented from acquiring property on Italian land. Mancipation over time becomes a burden for the Romans themselves. That is why Roman law, under the influence of ius gentium and the principle of bona fides, begins to slowly release from formalism.

Now, quirit property can be acquired even when the mancipation was not done (of course, this refers to res mancipi, since for res nec mancipi hand over was sufficient), through usucapion, and of course, with the fullfilled conditions for usucapion (expiration of a certain term, conscientiousness, res habilis - a thing eligible for the ownership of it can be acquired by usucapion, that the legal work is directed to the transfer of ownership, a continuous possession). The praetor who protected such a "qualified" holder with exceptio rei venditae et traditae and actio Publiciana also contributed to this. When Caracalla brought his famous edict in

\footnotetext{
${ }_{18}$ Gaius, Inst. 2. 29. Sed iura praedorium urbanorum in iure cedi tantum possunt.

${ }^{19}$ Gaius, Inst. 2. 30. Ususfructus in iure cessionem tantum recipit.

${ }^{20}$ Gaius, Inst. 2. 34. Hereditas quoque in iure cessionem tantum recipit.

${ }^{21}$ Gaius, Inst. 2. 25. Plerumque tamen et fere semper mancipationibus utimur.
} 
212, to which Roman citizenship was granted to all peregrines (except for dediticii - capitulated), the mancipation lost its legal political justifications. It was formally abolished in Justinian's law by replacing the term mancipatio in all legal texts with the term traditio. Therefore the provisions of the Institutes of Gaius (Gaius, Inst. 2. 22, 2322, 24, 25, 26, 27, 28, 29, 30, 31, 32, 33, 34, 35, 36, 37) that regulate mancipatio and in iure cessio were not taken in Justinian's.

Traditio (informal hand over) is also one of the derivative modes of acquiring property. Gaius points out that res nec mancipi is alienated simply by informal hand over, if they are cornal and eligible. ${ }^{23} \mathrm{He}$ gives an example of acquiring property by handing over a suit, gold or silver ${ }^{24}$, either on the basis of a sale, gift or other legal basis. ${ }^{25}$ The editors of the Institutes of Justinian have stated this in a more general way, respecting the changes made in Roman law, first of all the abolishing of mancipation (the division of things into res mancipi and res nec mancipi then becomes meaningless), making informal hand over (traditio) the only derivative way of acquiring property. Institutes of Justinian state that by natural law things are acquired by traditio, and that bodily things are disposed of by traditio. ${ }^{26} \mathrm{On}$ the other hand, they are introducing a new legal solution when it comes to the acquisition of property on the basis of the sale, by setting conditions on the acquisition of ownership of the property by the buyer to pay the price to the seller, so in this case it is not enough to hand over the property to the buyer ${ }^{27}$ Setting conditions of the transfer of ownership for the sold and delivered property to the purchaser by payment of the price was probably taken from Greek law. The following provisions have no role model in the Institutes of Gaius. As this is the only derivative mode of acquiring property, editors of the Institutes of Justinian could

${ }^{22}$ Article 23 of the Second Commentary of the Institutes of Gaius refers to Articles 119-123. of the First Commentary, which describe how the mancipation was perfomed, and these articles was abolished.

${ }^{23}$ Gaius, Inst. 2. 19. Nam res nec mancipi ipsa traditione pleno iure alterius fiint, si modo corporales sunt et ob id recipiunt traditionem.

${ }^{24}$ This rule also applies to estates in the province (Gaius, Inst. 2. 21. In eadem causa sunt provincialia praedia, quorum alia stipendaria alia tribotoria vocamus). The difference in the legal status of the land existed in Gaius time, because the Italian lands were res mancipi, so that the transfer of property on them required mancipation. In Justinian's law, the legal status of the land was equalized, so that the delivery was sufficient to acquire ownership of the land, as Institutes of Justinian also speak of (Just. Inst. 2. I. 40. ...itaque stpendaria quoque et tribotaria praedia eodem modo alienantur. Vocantur autem stipendaria et tributaria praedia, quae in provinciis sunt, inter quae nec non italica praedia ex nostra constitutione nulla differentia est).

${ }^{25}$ Gaius, Inst. 2. 20. Itaque si tibi vestem vel aurum vel argentum tradidero sive ex venditionis causa sive ex donationis sive quavis alia ex causa, statim tua fit ea res, si modo ego eius dominus sim.

${ }^{26}$ Just. Inst. 2. I. 40. Per traditionem quoque iure naturali res nobis adquiruntur...et ideo cuiuscumque generis sit corporalis res, tradi potest et a domino tradita alienatur...

${ }^{27}$ Just. Inst. 2. I. 41. ...venditae vero et traditae non aliter emptori adquiruntur, quam si is venditori pretium solverit... 
add regulations for different modes of handing things over. So the owner of the thing can hand over the things himself, but it can be done by someone else under his authority, ${ }^{28}$ and through the person to whom he entrusted the business ${ }^{29}$. Except these modes, they predict two types of so-called "fictive hand over" (traditio brevi manu and traditio longa manu), when the transfer of property rights occurs, but without handing over things. Traditio brevi manu implies that if a thing is sold or donated to one who already holds it on the basis of a contract of employment, inherit or rent there is no real act of hand over, because it has already been made on another legal basis. ${ }^{30}$ Traditio longa manu is a symbolic hand over of things (usually used to hand over real estate). The Institutes provide an example of handing over merchandise located in a granary, by handing over a granary keys. ${ }^{31}$

The original modes to acquire property are: occupation (occupatio), increment (accessio), specification (specificatio), mixing things (confusio, commixtio), finding a treasure (thesaurus), and usucapion (usucapio).

Occupation (occupatio) is take over of things that do not belong to anyone (res nullius) or abandoned things (res derelictae) ${ }^{32}$. For acquiring property this way, except possession, it is necessary that there is will to hold things for yourself (animo et corpore). Institutes of Justinian predict that the subject of occupation may be wild animals, birds, fish, all sea animals, air or land..$^{33}$ The second part of this article took over a provision from the Institutes of Gaius that states that if an animal escapes and returns to its natural freedom, it may become the property of the next one who capture them. ${ }^{34}$ For those animals that intent to go and come

${ }^{28}$ Just. Inst. 2. I. 42. Nihil autem interest, utrum ipse dominus tradat alicui rem, an voluntate eius alius.

${ }^{29}$ Just. Inst. 2. I. 43. Qua ratione, si cui libera negotiorum administratio a domino permissa fuerit isque ex his negotiis rem vediderit et radiderit, facit eam accipientis.

${ }^{30}$ Just. Inst. 2. I. 44. ...quam tibi aliquis commodavit aut locavit aut apud deposuit, vediderit tibi aut onaverit. Quamvis enim ex ea causa tibi eam non tradiderit, eo tamen ipso...

${ }^{31}$ Just. Inst. 2. I. 45. Item si quis merces in orreo depositas vendiderit, simul atque elaves horrei tradiderit emptori, transferit proprietatem mercium ad emptorem.

32 The occupation of abandoned things (res derelictae) is governed only by the Institutes of Justinian (Just. Inst. 2. I. 47. Qua ratione verius esse videtur et, si rem pro derelicto a domino habitam occupaverit quis, statim eum dominum effici). The things that get thrown off the ship are not really derelictae; he who takes them for the purpose of appropriation commits theft (Just. Inst. 2. I. 48. Alia causa est earum rerum, quae in tempestate maris levandae navis causa eiciuntur. Hae enim dominorum permanent...qua de causa si quis eas fluctibus expulsas vel etiam in ipso mari nactus lucrandi animo absulerit, furtum committit).

${ }^{33}$ Just. Inst. 2. I. 12. Ferae igitur bestiae et volucres et pisces, id est omnia animalia, quae in terra mari caelo nascuntur...

${ }^{34}$ Gaius, Inst. 2. 67. ....cum vero custodiam nostram evaresit et in naturalem libertatem se receperit, rursus occupantis fit, quia nostrum esse desinit... We can reasonably assume that the entire member of the Institutes of Gaius (Gaius, Inst. 2. 67.) has been taken over by the Justinian's (Just. Inst. 2. I. 12), since the first two lines of this article are illegible. However, after the illegible text, the words “....become our property as long as we keep it," (Gaius, Inst. 2. 67. ... eo usque nostrum 
back, such as pigeons, bees or deer, Justinian's Institutes (Just. Inst. 2. I. 15) have taken over the provision of the Gaius: "when they lose their intention to return, they stop being ours, and become the property of those who capture them." 35 And the next article of the Institutes of Gaius, which regulates the so-called occupatio bellica, is reciprocated in Justinian's (Just. Inst. 2. I. 17). It says: "And what we have taken from the enemy becomes our by the natural law." 36 . The following articles of the Institutes of Justinian do not have role model in the Gaius. There was a question in them - when a wounded animal becomes the property of a person, is it a wounding moment or a moment of capture? Compilers of the Institutes have decided that this is the moment of its capture. ${ }^{37} \mathrm{As}$ a rule, bees are wild, so they must be caught in order to gain ownership of them, and the same applies to those that swarm on wood. However, if they escape they can become the property of the one who catches them. ${ }^{38}$ Chickens and ducks are not wild in nature, which means that if they escape they remain the property of person who owned them. If someone else would then take them, it would be theft. ${ }^{39}$ The object of occupation may also be precious stones and similar objects found on the coast. ${ }^{40}$

Increment (accessio) is the case when one thing is attached to another so that it forms a whole. There are three groups of increments: the increment of the immovable thing immovable, the movable to immovible, and the increment of two movable things. There is the increment of the immovable thing immovable in the following cases: 1) alluvio - river silts (Just. Inst. 2. I. 20.) - decree taken from Gaius (Gaius, Inst. 2. 70.); 2) avulsio - "If the river has torn off part of your property and brought it to mine, that part remains yours ${ }^{641}$ (Just. Inst. 2. I. 21.) - a provision taken from the Gaius (Gaius, Inst. 2. 71.) ; 3) insula in flumine nata - an island formed in the middle of the river belongs to the coastal landowners and, if not in the middle, belongs to the nearest coastal landowners ${ }^{42}$ (Just. Inst. 2. I. 22.)

esse intellegitur, donec nostra custodia coerceatur;), which are almost the same (only instead of nostrum stands tuum) transcribed in Justinian's.

${ }^{35}$ Gaius, Inst. 2. 68. ...ut si revertendi animum habere desierint, etiam nostra esse desinant et fiant occupantium.

${ }^{36}$ Gaius, Inst. 2. 69. Ea quoque quae ex hostibus capiuntur naturali ratione nostra fiunt.

${ }^{37}$ Just. Inst. 2. I. 13. Illud quaesitum est, an, si fera bestia ita vulnerata sit, ut capi possit, statim tua esse intellegatur..

${ }^{38}$ Just. Inst. 2. I. 14. Apium quoque nauta fera est...

${ }^{39}$ Just. Inst. 2. I. 16. Gallinarum et anserum non est fera natura idque ex eo possumus intellegere...

${ }^{40}$ Just. Inst. 2. I. 18. Item lapilli gemmae et cetera...

${ }^{41}$ Justinian's Institutes in this article also contain an appendix in relation to Gaius, which provides that if trees from an infested piece of land root in the land of the owner of the adjacent land, the inflicted piece of land becomes the property of the owner of the neighbour land (Just. Inst. 2. I. 21....plane si longiore tempore funod vicini haeserit arboresque, quas secum traxerit in eum fundum radices egerint, ex eo tempore videntur vicini funod adquisitae esse).

${ }^{42}$ The article contains an additional provision for an island that appears in the sea (insula in mari nata). In this case, the island becomes the property of the one who appropriates it (Just. Inst. 
- a decree taken from the Gaius (Gaius, Inst. 2. 72.); 4) alveus derelictus - abandoned riverbed (Just. Inst. 2. I. 23.) -a decree has no role model in the Institutes of Gaius. The basic rule of increment a moving thing to immobile is superficies solo cedit. These include: 1) the construction on their land with someone's material (inaedificatio), for which the case of the Institutes of Justinian provides that the building belongs to the owner of the land. ${ }^{43}$ This article (not taken from the Institutes of $G a$ ius) invokes the Law of the Twelve Tables and the actio de tigno iuncto, which belonged to the owner of the material and voted for twice the value of the incorporated material, was introduced in order to avoid demolition of buildings. However, as soon as the building is demolished for any reason, the provision in question entitles the owner of the material to actio rei vindicatio or actio ad exhibitoria ${ }^{44}$; 2 ) In the article of the Institutes of Justinian (Just. Inst. 2. I. 30), which reciprocated the Gaius provision, ${ }^{45}$ provided that if one used the material to build a building on someone else's land (inaedificatio), then the building belonged to the landowner; 3 ) this rule applies to planting on someone else's land (implantatio - Just. Inst. 2. I. 31. the corresponding provision is Gaius, Inst. 2.74); as well as sowing on someone else's land (satio - Just. Inst. 2. I. 32. the corresponding provision is Gaius, Inst. 2.75). The same principle applies to the growth of two moving things: 1) textura - if the thread is woven into someone else's suit, then the thread becomes the property of the one whose suit it is. ${ }^{46}$ The provision wasn't taken from the Institutes of Gaius; 2) scriptura - what someone wrote on someone else's paper or papyrus follows the legal fate of the paper or papyrus, "even if he wrote in gold letters". ${ }^{47}$ This legal solution was also accepted in the Institutes of Justinian (Just. Inst. 2. I. 33); 3) pictura - the opposite view was adopted here, because if someone painted a painting on someone else's material (plate, canvas), then that material also becomes the property of the painter, provided that the previous owner is compensated for the value of the material, otherwise it may be rejected by objection (exceptio doli), if the painter is the owner of the material he can be sue for the reasons of utility (utilis causa). ${ }^{48}$ This provision was also taken over (Just. Inst. 2. I. 34).

2. I. 22. Insula, quae in mari nata est, quod rare accidit, occupantis fit). It should be borne in mind that this is an occupation, not an increment.

${ }^{43}$ Just. Inst. 2. I. 29. Cum in suo solo aliquis aliena materia aedificaverit, ipse dominus intellegitur aedificii...

${ }^{44}$ Just. Inst. 2. I. 29 ...sed si aliqua ex causa dirutum sit aedficium, poterit materiae dominus, si non fuerit duplum iam persecutus, tunc eam vindicare et ad exhibendum agere.

${ }^{45}$ Gaius, Inst. 2. 73. Praetera id quod in solo nostro ab aliquo aedficatum est, quamis ille suo nomine aedificaverit, iure naturali nostrum fi...

${ }^{46}$ Just. Inst. 2. I. 32. Si tamen alienam purpuram quis intexuit suo vestimento, licet pretiosior est purpura, accessionis vice cedit vestimento...

${ }^{47}$ Gaius, Inst. 2. 77. ...quod in chartulis sive membranis meis aliquis scripserit, licet aureis litteris, meum esse...

${ }^{48}$ Gaius, Inst. 2.78. Sed si in tabula mea aliquis pinxerit veluti imaginem, contra probatur; magis enim dicitur tabulam picturae cedere. Cuius diversitatis vix idonea ratio redditur; certe 
When we speak of specification (specificatio), Gaius was in a dilemma to whom the processed thing belongs, whether to the owner of the material ${ }^{49}$ or the processor $^{50}$. Institutes of Justinian predict an intermediate solution - if the thing can return to the state of the raw material, then it belongs to the owner of the material, and if it cannot, then the processor. ${ }^{51}$

Mixing things or confusion (confusio, commixtio) exists when the liquid or solid things of different owners are mixed, but so that no increment or specification is created. Gaius does not mention confusion. The Institutes of Justinian cite an example of the willing or accidental mixing of wines by two different owners (confusio), and predict that in this case there is a co-existence, as well as the situation when the cereals are mixed by two or more different owners (comixtio). ${ }^{52}$ If this is done voluntarily, then a co-ownership occurs on the whole grain and each co-owner can claim his share through actio communi dividundo; accidental mixing does not lead to co-ownership, and if one of the co-owners takes such a mixed amount of grain, the other is entitled to actio in rem..$^{53}$

Gaius says nothing about finding the treasure (thesaurus) as a mode of acquiring property. The Institutes of Justinian contain one article which refers to Hadrian's provision that when one discovers a treasure in his land, then it belongs to him, but if he finds the treasure in someone else's land, then the treasurer and the inventor would be divided in half. ${ }^{54}$

\section{USUCAPION}

Usucapio (usus - usage, use, and capere - acquire, gain) is a mode of acquiring property on someone else's property through its continued use over a period of time provided for by law. Gaius and Justinian's textbook of law regulate usucapion. Introduction of Chapter VI De usucapionibus et longi temporis possessionibus of

secundum hanc regulam si me possidente petas imaginem tuam esse, nec solvas pretium tabulae, poteris per exceptionem doli mali summoveri; at si tu possideas, consequens est, ut utilis mihi actio adversarum te dari debeat...

${ }^{49}$ Gaius, Inst. 2. 79. ...Quidam materiam et substantiam spectandam esse putant, id est ut cuius materia sit, illus et res, quae facta sit, videatur esse...

${ }^{50}$ Gaius, Inst. 2.79. ....Alii veroeius rem esse putant qui fecerit...

${ }^{51}$ Just. Inst. 2. I. 25. ...si ea species ad materiam reduci possit, eum videri dominum esse, qui materiae dominus fuerat, si non possit reduci, eum potius intellegi dominium qui fecerit...

52 Just. Inst. 2. I. 27. Si duorum materiae ex voluntate dominorum confusae sint, totum id corpus quod ex confusione fit, utriusque commune est, veluti si qui vina sua confuderint...

${ }_{53}$ Just. Inst. 2. I. 28. ...sed si ab abterutro vestrum id totum frumentum retineatur, in rem quidem actio pro modo frumenti cuiusque competat...

${ }^{54}$ Just. Inst. 2. I. 39. Thesauros, quos quis in suo loco invenerit, divu Hadrianus naturalem aequitatem secutus ei concessit qui invenerit... at si quis in alieno loco non data ad hoc opera, sed fortuitu invenerit, dimidium domino soli concessit. 
the The Institutes of Justinian contains two provisions from the Institutes of Gaius. The first, which says that a thing can be acquired through the usucapion by a non-proprietor provided that the thing is received conscientiously, ${ }^{55}$ ie. in the belief that the transferor is at the same time its owner, ${ }^{56}$ and the other, which prescribes two years for the holding of immovable or one year for usucapion of movable property ${ }^{57}$ The continuation of the Institutes of Justinian, these terms are extended by the constitution to 3 years for movable property, and for immovable property to 10 years (inter praesentes) and 20 years (inter absentes). ${ }^{58}$ The provision according to which free people, religious and sacral things cannot be the object of usucapion, ${ }^{59}$ was taken up (Just. Inst. 2. VI. 1). According to the Law of the Twelve Tables the object of usucapion cannot be stolen things, and according to the Julius and Plautius Law things abducted from somebody. ${ }^{60}$ This article is also reciprocated (Just. Inst. 2. VI. 2). Not only a thief and a hijacker cannot gain something by usucapion, but neither can any other person, even if the thing is obtained in good faith and on a legal basis. ${ }^{61}$ This provision was also taken over ${ }^{62}$ (Just. Inst. 2. VI. 3). There are cases when it is possible to usucapion an item that doesn't belong to the transferor, since he has no intent to steal (affectus furandi). The first case is when the heir, by acting in good faith, alienates (sells, give) to a conscientious acquirer a thing which was not in the estate of the deceased but was leased or given to him;63 the second is when the landloard, believing that the slave-owner alienates her child; ${ }^{64}$ and there are other cases in which another's property may be handed over

${ }^{55}$ However, Justinian's institutions, unlike the Gaius, point out that it does not matter whether it is a sale, gift or other legal basis for the transfer of property (Just. Inst. 2. VI. ...rem emerit, vel ex donatione aliave qua iusta causa...).

${ }^{56}$ Gaius, Inst. 2. 43. Ceterum etiam earum rerum usucapio nobis conpetit, quae non a domino nobis traditae fuerint...si modo eas bona fide acceperimus...

${ }^{57}$ Gaius, Inst. 2. 42. Usucapio autem mobilium quidem rerum anno completur, fundi vero et aedium biennio...

${ }^{58}$ Just. Inst. 2. VI. ...et ideo constitutionem super hoc promulgavimus, qua autum est, ut res qiudem mobiles per triennium usucapiantur. Immobiles vero per longi temporis possessionem, id est inter praesentes decennio, inter absentes viginti annis...

${ }^{59}$ Gaius, Inst. 2. 48. ... liberos homines et res sacras et religiosas usucapi non posse manifestum est.

${ }^{60}$ Gaius, Inst. 2. 45....nam furtivam lex XII tabularum usucapi prohibet, vi possessam lex Iulia et Plautia.

${ }^{61}$ Gaius, Inst. 2. 49. ...ut ne ipse fur quive vim possidet, usucapere possit...sed nec ullus alius; quamquam ab eo bona fide emerit, usucapiendi ius habeat.

62 Except these, the Institutes of Justinian foresee that it is not possible to maintain things belonging to fiscus (Just. Inst. 2. VI. 9. Res fisci nostri usucapi non potest ...), as well as those in the view that there is a delusion (Just. Inst. 2. VI. 11. Error autem falsae cause usucapionem non parit...).

${ }^{63}$ Gaius, Inst. 2. 50. ...nam si heres rem defuncto commodatam aut locatam vel apud eum depositam existimans eam esse hereditariam vendiderit aut donaverit, furtum non committit...

${ }^{64}$ Gaius, Inst. 2. 50. ...item si is, ad quem ancille ususfructus pertinet, partum etiam suum esse credens vendiderit aut donaverit, furtum non committit... 
to another without theft being committed so that the acquirer may acquire the property by usucapion. ${ }^{65}$ This article is reciprocated in the Institutes of Justinian into three articles (Just. Inst. II. VI. 4, 5, 6). A holder of someone else's land abandoned by the owner's negligence, or the owner's death without an heir or has been away for a long time, may acquire the land by usucapion, and may transfer the land to another person, who may acquire it by usucapion, if he was conscientious. ${ }^{66}$ The Institutes of Justinian have taken over this provision (Just. Inst. 2. VI. 7).

Institute based counting of time required for usucapion (accessio temporis) is regulated only by the Institutes of Justinian (Just. Inst. 2. VI. 12, 13, 14). On the other hand, the usucapion in the name of the heirs (usucapio pro herede) and usureception (usureceptio) are legal institutes that are not known in Justinian's law and are not regulated by his Institutes, and therefore the articles which were dedicated to them are not taken over from the Institutes of Gaius (Gaius, Inst. 2. 52, 53, $54,55,56,57,58,59,60,61)$.

\section{SERVITUDE}

Servitude (servitutes) represent proper rights to other people's things (iura in re aliena). It is a heterogeneous group of proper rights, which allow their titulars to use others property. The common division of servitude is into land servitudes (servitutes praediorum) and personal servitudes (servitutes personarum). The basic criterion for this division could be reduced to the question for whose benefit it is established? If servitude is constituted for the easier or better use of a particular immovable property ${ }^{67}$, no matter who is the titular of this right, it is a land servitude, and if it is established for the benefit of a specific person, then it is a matter of personal servitude. Land servitudes are divided into rural (praediorum rusticorum) and urban (praediorum urbanorum), and personal are usufruct (ususfructus), right of use (usus), right of habitation (habitatio) and right to use the labor of another's slave or animal (operae servorum vel animalium). When we speak of land servitudes (servitutes praediorum), the Institutes of Gaius ${ }^{68}$ were

${ }^{65}$ Gaius, Inst. 2. 50. ...Aliis quoque modis accidere potest, ut quis sine vitio furti rem alienam ad aliquem transferat et efficiat, ut a possessore usucapiatur.

${ }^{66}$ Gaius, Inst. 2. 51. Fundi quoque alieni potest aliquis sine vi possessionem nancisci, quae vel ex neglegentia domini vacet, vel quia, dominus sine successore decesserit vel longo tempore afuerit; quam si ad alium bona fide accipientem transtulerit, poterit usucapere possessor...

${ }^{67}$ Real estate on which servitude exists is called praedium serviens, and real estate in favor of which servitude is constituted for ease or better use is called praedium dominans.

${ }^{68}$ Gaius states that city land easements are transferred only by way of a judicial assignment (in iure cessio), and rural can by mancipation (Gaius, Inst. 2. 29. Sed iura praediorum urbanorum in iure cedi tantum possunt; rusticorum vero etiam mancipari possunt), which of course does not accept Justinian's right, since these ways of constituting real rights have been abolished. 
not the source of the Institutes of Justinian. These servitudes were regulated in the chapter De Servitutibus III of the Second Book of the Institutes of Justinian. The introduction discusses rural servitudes (rusticorum praediorum iura), which include: 1) iter - the right to pass by walking; 2) actus - the right to chase cattle; 3) via - the right to pass by tandem and 4) aquaeductus - conducting water over someone else's land (Just. Inst. 2. III) ${ }^{69}$ The rural servitudes are: 1) aquehaustus - the right to take water from another's land (wells); 2) servitus pecoris ad apulsus - the right to water cattle on someone else's land (this servitude also includes servitus actus); 3) servitus (ius) pascende - the right to graze and 4) servitus calcis coquendae - the right to make calx; 5) servitus harenae fodiendae - right to dig and take sand (Just. Inst. 2. III. 2). The urban servitudes (praediorum urbanorum) ${ }^{70}$ are: 1) servitus tigni immitendi - the right to install their beams in someone else's wall; 2) servitus stillicidi - drainage of rainwater from the roof onto the neighbor's land; 3) servitus altius non tollendi - not to raise (or at least to a certain height) buildings and 4) servitus ne liminibus officiatur - not to obscure light (Just. Inst. 2. III. 1). In Justinian's law, land servitudes are constituted by an informal agreement, stimulations or testament. ${ }^{71}$

Usufruct (ususfructus) is the right to use and enjoy one thing without touching its essence. ${ }^{72}$ The Institutes of Gaius do not contain this definition, but merely provide modes of constituting this servitude: 1) in iure cessio ${ }^{73}$; 2) informal agreements and stipulations for the usufrucut of provincial lands ${ }^{74}$; 3) deductio servitutis during mancipation ${ }^{75}$. The mentioned provisions of the Institutes of Gaius, which provide different ways of constituting usufruct, couldn't be role model to the editors of the Institutes of Justinian, since in iure cessio and mancipatio were the legal institutes, that didn't exist in post-classical Roman law. As the legal regime of the provincial and Italian lands was even, the regime was for constituting

${ }^{69}$ These servitudes used to be res mancipi by ius civile.

${ }^{70}$ Urban servitudes are attached to buildings, where their name comes from, so urban servitudes exists even when the building is located in the countryside (Just. Inst. 2. III. 1. Praediorum urbanorum sun servitutes, quae aedificiis inhaerent, ideo urbanorum praediorum dictae, quoniam aedificia omnia urbana praedia appelantur, etsi in villa aedificata sunt).

${ }^{71}$ Just. Inst. 2. III. 4. Si quis velit vicino aliquod ius constituere, pactionibus atque stipulationibus id efficere debet. potest etiam in testamento... During Gaius time, easements were established by informal agreements and stimulations only on provincial land (Gaius, Inst. 2. 31. Alioquin in provincialiubus praedis sive quis usumfructum sive ius eundi agendi aquamve ducendi vel altius tollendi aedese aut non tollendi, ne luminibus vicini officiatur, ceterque iura consistuere velit, pactionibus et stipulationibus id efficere potest...).

72 Just. Inst. 2. IV. Ususfructus est ius alienis rebus utendi fruendi salva rerum substantia.

${ }^{73}$ Gaius, Inst. 2. 30. Ususfructus in iure cessionem tantum recipit.

${ }^{74}$ Gaius, Inst. 2. 31. Alioquin in provincialiubus praedis sive quis usumfructum...pactionibus et stipulationibus id efficere potest...

${ }^{75}$ Gaius, Inst. 2. 33. ...non enim ipse ususfructus mancipatur, sed cum in mancipanda proprietate deducatur, eo fit ut apud alium ususfructus, apud alium proprietas sit. 
usufruct (but also other servitudes) and they became unique. According to the Institutes of Justinian the legal basis for constituting usufruct was informal agreements, stipulations, legacies or deductio usu fructu on the basis of the testament (Just Inst. 2. IV. 1). Usufruct could only be constituted on non-consumable items (land, building, goods, animal) but not on consumable items, and that such a rule was until the Senate decided that usufruct could also be established on consumable items (for example, on money), with the fact that the thing is transferred to the property of the beneficiary, and he bails (cautio ususfructus) that he will repay the same amount over the period of time (death or capitis deminutio). The Senate didn't predict real usufruct over these matters, but something resembling usufruct (quasi ususfructus), through bail. ${ }^{76}$ Usufruct stops with the death of the titular of the usufruct, and as a result of capitis deminutio maxima and the media titular of the usufruct, by not using this right in a certain way or for a certain period of time, giving up to the owner, consolidation, the collapse of the thing that was the subject of the usufruct. ${ }^{77}$ When the usufruct ceases, the owner, who until then had only "bare property," from that moment on, regains "complete authority on things."

The Institutes of Gaius do not contain provisions for other personal servitudes. Institutes of Justinian predict that the right of use (usus) arises and disappears just as usufruct, ${ }^{79}$ as well as it is less than usufruct, because it gives the titular the right to use only the thing but not to acquire the fruits. ${ }^{80}$ One who has a right of habitation (habitatio) can live in the house, but cannot transfer that right to another. ${ }^{81}$ Also, anyone who has the right to use the labor of another's slave or animal (operae servourum vel animalium) can use their work only for their own business, but cannot transfer that right to another. ${ }^{82}$

\section{CONCLUSION}

The paper identifies which provisions governs the institutes of Roman property law of the Institutes of Gaius were, or could be, role model of the Institutes of

${ }^{76}$ Just. Inst. 2. IV. 2. ...ergo senatus non fecit quidem earum rerum usum fructum (nec enim poterat), sed per cautionem quasi usum fructum constitut.

${ }^{77}$ Just. Inst. 2. IV. 3. Finitur autem usus fructus morte fructuarii et duabus capitis deminutionibus, maxima et media, et non utendo per modum et tempus...

${ }^{78}$ Just. Inst. 2. II. 4. Cum autem finitus fuerit usus fructus, revertitur scilicet propiretatem et ex eo tempore nudae proprietatis dominus incipit plenam habere in re potestatem.

79 Just. Inst. 2. V. Isdem istis modis, quibus usus fructus constituitur...

${ }^{80}$ Just. Inst. 2. IV. 1. Minus autem scilicet iuris usu est quam in usu fructu...

${ }^{81}$ Just. Inst. 2. IV. 2. Item is, qui aedium usum habet, hactenus iuris habere intellegitur, ut ipse tantum habitet, nec hoc ius ad alium transferre potest...

${ }^{82}$ Just. Inst. 2. IV. 3. Item is, ad quem servi usus pertinet. ipse tantum operis atque ministerio eius uti potest: ad alium vero nullo modo ius suum transferre et concessum est. idemscilicet iuris est et in iumento. 
Justinian. The term of things (res) doesn't define either. The Institutes of Gaius had some influence over the Justinian's in the legal regime of certain things, especially when it came to matters outside the legal trade, whether they were outside the of legal circulation "by human law" (res extra commercium humani iuris) or "by divine law" (res extra commercium divini iuris). Also, the division of things into corporeal (res corporales) and not-corporeal (res incorporales) was literally taken over, but in Justinian's law it had only theoretical significance, since the state of not-corporeal things (quasi possessio) was introduced. The division of things into res mancipi and res nec mancipi also lost its significance by abolishing mancipation (mancipatio), so the provisions on those things were not taken over. Property was indirectly defined by Institutes of Justinian. The derivative modes of acquiring the property of the ius civile (mancipatio and in iure cessio), spoken of by Gaius, ceased to exist in post-classical Roman law, so Justinian's law predict only traditio. In terms of original modes of acquiring property, such as occupation (occupatio), increment (accessio) and specification (specificatio), the Institutes of Gaius were a role model to Justinian's, but when it came to confusion (confusio, commixtio) and finding the treasure (thesaurus) are not. Usucapion provisions (usucapio) were reciprocated from the Gaius, with modifications to the time required for usucapion, while servitude provisions (servitutes) weren't taken over, but they are inovation in relation to the Institutes of Gaius.

\section{REFERENCES}

Бакотић Лујо, Caesar Flavius Justinianus: Institutiones, Београд 1912. Станојевић Обрад, Гај, Инстиийуиије, Београд 2009. 


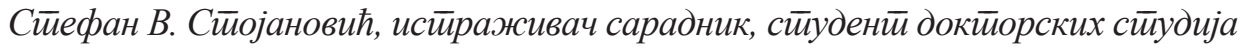
Универзийей у Нищиу

Иновациони иенитар

stojanovicst91@gmail.com

\section{Римско стварно право у упоредној анализи Гајевих Институција и Јустинијанових Институција}

Сажейак: У раду је изврщено уйоређивање одредаба римског̄ стиварног̄ йрава у Гајевим и Јустиинијановим Инстиитучијама. Циљ рада је да оимкрије које су одредбе Гајевих Инстиитучија реиийиране у Јустиинијановим, а које нису, иее да ли су йоједине одредбе ирреузете уз модификаиију и у чему

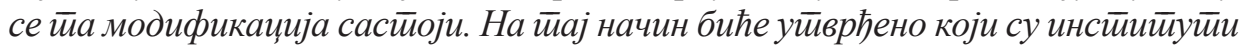
римског̄ стиварног̄ йрава остиали неизмењени до Јустиинијановог времена, који су иретириели ирромене, а који су услед иромена у друщитвеним односима

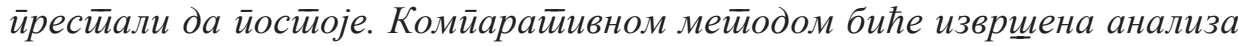
најважнијих йравних йојмова и инстиийуйа римског стиварног̄ ӣрава из Инстиийуција.

Кључне речи: римско йраво, симварно ӣраво, Гајеве Инсӣийуције, Јусиичнијанове Инстиитуције.

Датум пријема рада: 11.9.2019. 